\title{
Photocytotoxic ternary copper(II) complexes of histamine Schiff base and pyridyl ligands
}

\author{
SAMYA BANERJEE $^{\mathrm{a}}$, AKANKSHA DIXIT $^{\mathrm{b}}, \mathrm{K}$ SESHA MAHESWARAMMA ${ }^{\mathrm{a}}$, \\ BASUDEV MAITY ${ }^{\mathrm{a}}$, SANJOY MUKHERJEE ${ }^{\mathrm{a}}$, ARUN KUMAR ${ }^{\mathrm{a}}$, ANJALI A KARANDE ${ }^{\mathrm{b}, *}$ \\ and AKHIL R CHAKRAVARTY ${ }^{\mathrm{a}, *}$ \\ ${ }^{a}$ Department of Inorganic and Physical Chemistry, Indian Institute of Science, Bangalore 560 012, India \\ ${ }^{b}$ Department of Biochemistry, Indian Institute of Science, Bangalore 560 012, India \\ e-mail: anjali@biochem.iisc.ernet.in; arc@ipc.iisc.ernet.in
}

MS received 19 October 2015; accepted 21 November 2015

\begin{abstract}
Ternary copper(II) complexes of salicylaldehyde-histamine Schiff base (HL) and pyridyl ligands, viz. $[\mathrm{Cu}(\mathrm{bpy})(\mathrm{L})]\left(\mathrm{ClO}_{4}\right)(\mathbf{1})$ and $[\mathrm{Cu}(\mathrm{dppz})(\mathrm{L})]\left(\mathrm{ClO}_{4}\right)(\mathbf{2})$, where bpy is $2,2^{\prime}$-bipyridine (in $\left.\mathbf{1}\right)$ and dppz is dipyrido[3,2-a: $2^{\prime}, 3^{\prime}$-c]phenazine (in 2), were synthesized, characterized and their DNA binding, photo-activated DNA cleavage activity and photocytotoxicity studied. The 1:1 electrolytic one-electron paramagnetic complexes showed a $d$ - $d$ band near $670 \mathrm{~nm}$ in aqueous DMF $(1: 1 \mathrm{v} / \mathrm{v})$. The crystal structure of complex 1 showed the metal in $\mathrm{CuN}_{4} \mathrm{O}$ distorted square-pyramidal geometry. Complex $\mathbf{2}$ intercalatively binds to calf-thymus (ct) DNA with a binding constant $\left(K_{\mathrm{b}}\right)$ of $\sim 10^{5} \mathrm{M}^{-1}$. It exhibited moderate chemical nuclease activity but excellent DNA photocleavage activity in red light of $647 \mathrm{~nm}$ forming ${ }^{\bullet} \mathrm{OH}$ radicals. It showed remarkable photocytotoxicity in human cervical cancer cells (HeLa) giving $\mathrm{IC}_{50}$ of $1.6 \mu \mathrm{M}$ in visible light $(400-700 \mathrm{~nm}$ ) with low dark toxicity. The photo-induced cell death is via generation of oxidative stress by reactive oxygen species.
\end{abstract}

Keywords. Copper; dipyridophenazine; medicinal chemistry; photocytotoxicity; apoptosis.

\section{Introduction}

Photoactive metal complexes with their tunable coordination geometry, versatile redox and spectral properties are of current interest as the non-porphyrinic metal-based photochemotherapeutic agents for cancer treatment. ${ }^{1-7}$ Such metal complexes can be selectively activated by low energy visible light to display cytotoxicity in the cancer cells, while remaining non-cytotoxic in the dark. They act as potential alternatives to the FDA approved photodynamic therapy (PDT) drug Photofrin ${ }^{\circledR} .{ }^{8-12}$ PDT as a promising therapeutic methodology has received considerable attention due to its non-invasive nature, reduced side effects, and for its tumor selective mode of action leaving the normal cells unaffected. ${ }^{13-16}$ The organic PDT agents on photoactivation in red light generally form cytotoxic singlet oxygen $\left({ }^{1} \mathrm{O}_{2}\right)$ as the reactive oxygen species via type-II pathway. ${ }^{14,15}$ The porphyrin dyes are known to lead skin irritation and hepatotoxicity due to formation of bilirubin on oxidative degradation. ${ }^{14,16}$ In contrast, redox active $3 \mathrm{~d}$-metal complexes could show visible light induced photocytotoxicity by an alternate photo-redox pathway forming hydroxyl radicals as the reactive oxygen species (ROS). ${ }^{17-19}$ Sadler et al. have recently developed a new strategy to increase the

\footnotetext{
*For correspondence
}

efficacy and to overcome the intrinsic resistance of the platinum based drugs by photo-activating platinum(IV) prodrugs specifically within the target cancer cells, thus not damaging the unexposed normal cells..$^{1,3,20,21}$ A new model in PDT is reported for an azopyridine manganese complex $\left[\mathrm{Mn}(\right.$ azpy $\left.) \mathrm{Br}(\mathrm{CO})_{3}\right]$ showing release of cytotoxic carbon monoxide $(\mathrm{CO})$ on exposure to low energy visible light leading to cellular apoptosis. ${ }^{22}$ Dunbar, Turro and co-workers have reported various polypyridyl ruthenium(II) complexes having photoactive terpyridine and biologically active 5CNU moieties (5CNU, 5-cyanouracil) that are photocytotoxic upon visible light irradiation. ${ }^{23,24}$ We have recently reported several metal-based photo-chemotherapeutic agents which show efficient DNA photocleavage and photocytotoxic activity in various cancer cells in visible or near-IR red light. ${ }^{25-30}$ In addition, dichloro-oxovanadium(IV) complexes are shown to form photo-induced ds-DNA crosslinks resulting apoptotic cell death. ${ }^{31}$

The present work stems from our interest to design new copper(II) complexes that are capable of cleaving DNA in near IR red light and show visible light induced photocytotoxicity with low dark toxicity. Copper is a bioessential element and copper(II) complexes are reported as anticancer agents and extensively used as synthetic nucleases. ${ }^{2,32}$ Further, copper(II) complexes 
showing a low energy metal centered d-d band within the PDT spectral window of 600-800 nm are suitable for PDT applications with their excellent DNA photocleavage activity in near IR light. Herein, we present the synthesis, characterization, DNA binding, DNA photocleavage activity and visible light-induced photocytotoxicity of two new ternary copper(II) complexes, viz., $[\mathrm{Cu}($ bpy $)(\mathrm{L})]\left(\mathrm{ClO}_{4}\right)(\mathbf{1})$ and $[\mathrm{Cu}(\mathrm{dppz})(\mathrm{L})]\left(\mathrm{ClO}_{4}\right)$ (2), where bpy is $2,2^{\prime}$-bipyridine (in $\mathbf{1}$ ), dppz is dipyrido[3,2-a:2', 3'-c]phenazine (in 3) and $\mathrm{L}$ is the monoanionic form of salicylaldehyde-histamine Schiff base (figure 1). Complex $\mathbf{1}$ is structurally characterized by X-ray crystallography. The planar phenazine moiety in $\mathbf{2}$ is expected to show dual activity with its intercalative DNA-binding and excellent photosensitizing abilities. We have used the salicylaldehyde Schiff base of histamine considering its inherent anti-tumorigenesis activity. ${ }^{33,34}$ The planar polypyridyl ligands are well known for their intercalative DNA binding, photoactivity and preferential nuclear uptake., ${ }^{8,9,19,25}$ Significant results of this study include remarkable DNAphotocleavage activity in red light involving hydroxyl radicals $(\mathrm{OH})$ and visible light induced photocytotoxicity of $[\mathrm{Cu}(\mathrm{dppz})(\mathrm{L})]\left(\mathrm{ClO}_{4}\right)(2)$ in HeLa cells with low cytotoxicity in the dark. The cell death is found to be via apoptotic pathway involving photo-induced generation of intracellular reactive oxygen species (ROS).

\section{Experimental}

\subsection{Materials and Methods}

All the chemicals and reagents were purchased from various commercial sources (SD Fine Chemicals, India;

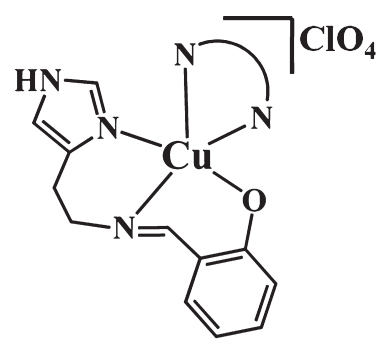

\section{$(1,2)$}

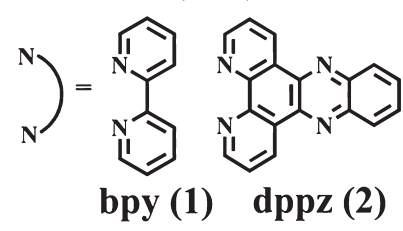

Figure 1. Schematic diagram of the copper(II) complexes $\mathbf{1}$ and $\mathbf{2}$ and the ligands used.
Aldrich, USA) and used as such without any further purification. Solvents used were purified by standard procedures. ${ }^{35}$ Calf thymus (ct) DNA, Dulbecco's phosphate buffered saline (DPBS), ethidium bromide (EB), Hoechst 33258, 3-(4,5-dimethylthiazol-2-yl)-2,5-diphenyltetrazolium bromide (MTT), 2',7'-dichlorofluoresceindiacetate (DCFDA), agarose (molecular biology grade), distamycin, catalase, superoxide dismutase (SOD), 2,2,6,6-tetramethyl-4-piperidone (TEMP), propidium iodide (PI), Dulbecco's modified eagle medium (DMEM) and fetal bovine serum (FBS) were purchased from Sigma (USA). Tris-(hydroxymethyl)aminomethane-HCl (Tris-HCl) buffer was prepared using deionized and sonicated triple distilled water using a quartz water distillation setup. The $N, N$,-donor heterocyclic base, viz. dipyrido[3, 2-a:2', 3'-c]phenazine (dppz), was synthesized following the literature procedures. ${ }^{36}$ Tetrabutylammonium perchlorate (TBAP) was prepared from tetrabutylammonium bromide and perchloric acid.

The elemental analyses were carried out using a Thermo Finnigan Flash EA 1112 CHNS analyser. The infrared (IR) and electronic spectra were recorded using Bruker Alpha and Perkin-Elmer Spectrum 650 spectrophotometers, respectively, at $25^{\circ} \mathrm{C}$. Molar conductivity measurements were made using a Control Dynamics (India) conductivity meter. Electrospray ionization (ESI) mass spectral measurements were done using Agilent 6538 Ultra high definition (UHD) accurate Mass-QTOF (LC-HRMS) model mass spectrometer. ${ }^{1} \mathrm{H}$ NMR spectra were recorded at room temperature on a Bruker $400 \mathrm{MHz}$ NMR spectrometer. Flow cytometric analysis was performed using FACS Calibur (Becton Dickinson (BD) cell analyzer) at FL1 channel (595 nm).

\subsection{Synthesis of the complexes}

The complexes were prepared by following a general synthetic procedure. A mixture of histamine dihydrochloride $(0.184 \mathrm{~g}, 1 \mathrm{mmol})$ was initially reacted with triethylamine $(0.202 \mathrm{~g}, 2 \mathrm{mmol})$ under stirring in $\mathrm{MeOH}$ $(15 \mathrm{~mL})$ for $15 \mathrm{~min}$ and then salicylaldehyde $(0.122 \mathrm{~g}$, $1 \mathrm{mmol}$ ) was added slowly. The resulting mixture was heated to reflux for $1 \mathrm{~h}$ with continuous stirring. The color of the solution changed to bright yellow indicating formation of salicylaldehyde-histamine Schiff base. In a separate flask, copper(II) nitrate $(0.24 \mathrm{~g}, 1 \mathrm{mmol})$ was dissolved in $15 \mathrm{~mL}$ aqueous $\mathrm{MeOH}(1: 4 \mathrm{v} / \mathrm{v})$. A methanol solution $(10 \mathrm{~mL})$ of $2,2^{\prime}$ bypyridyl $(0.156 \mathrm{~g}$, $1 \mathrm{mmol})$ for complex $1 \mathrm{or} \mathrm{dppz}(0.282 \mathrm{~g}, 1 \mathrm{mmol})$ for complex 2 was added slowly into the copper(II) nitrate solution. The resulting blue colored solution was stirred for $1 \mathrm{~h}$ at room temperature. The solution was cooled 
to $0^{\circ} \mathrm{C}$ using ice bath and the Schiff base solution was added slowly with continued stirring for $1 \mathrm{~h}$. The solution turned to green color due to the formation of ternary complexes. Sodium perchlorate was added to this solution under stirring for another $15 \mathrm{~min}$. The complex was precipitated out as a green solid which was collected by filtration, washed with cold methanol and diethyl ether and finally dried in vacuum over $\mathrm{P}_{4} \mathrm{O}_{10}$.

2.2a $[\mathrm{Cu}($ bpy $)(\mathrm{L})]\left(\mathrm{ClO}_{4}\right)(1)$ : [Yield: 78\%] Analysis: Calculated for $\mathrm{C}_{22} \mathrm{H}_{20} \mathrm{ClCuN}_{5} \mathrm{O}_{5}: \mathrm{C}, 49.54 ; \mathrm{H}, 3.78 ; \mathrm{N}$, $13.13 \%$. Found: C, 49.83; H, 3.86; N, 13.10\%. ESI-MS in MeCN: $m / z 433.0978\left[\mathrm{M}-\mathrm{ClO}_{4}\right]^{+}$. IR / cm ${ }^{-1}: 3360 \mathrm{~m}$, 1626 vs, 1532 m, 1444 m, 1354 s, 1091 vs, 763s, 625 w (vs, very strong; s, strong; m, medium; w, weak; br, broad). UV-visible in $50 \%$ aqueous DMF $\left[\lambda_{\max } / \mathrm{nm}\right.$ $\left(\varepsilon / \mathrm{M}^{-1} \mathrm{~cm}^{-1}\right)$ ]: 673 (65), 361 (3400), 273 (15700). $\mu_{\mathrm{eff}}$ at $298 \mathrm{~K}: 1.84 \mu_{\mathrm{B}}$. Conductivity in $\operatorname{DMF}\left(\Lambda_{\mathrm{M}}\right): 72 \mathrm{~S}$ $\mathrm{cm}^{2} \mathrm{M}^{-1}$.

2.2b [Cu(dppz)(L)](ClO $\left.\mathrm{Cl}_{4}\right)(2)$ : [Yield: 72\%] Analysis: Calculated for $\mathrm{C}_{30} \mathrm{H}_{22} \mathrm{ClCuN}_{7} \mathrm{O}_{5}: \mathrm{C}, 54.63 ; \mathrm{H}, 3.36 ; \mathrm{N}$, $14.87 \%$. Found: C, 54.37; H, 3.47; N, $14.95 \%$. ESIMS in MeCN: $m / z 559.1211\left[\mathrm{M}-\mathrm{ClO}_{4}\right]^{+}$. IR / $\mathrm{cm}^{-1}$ : $3425 \mathrm{~m}, 2918$ br, 1621 vs, $1537 \mathrm{w}, 1458$ s, $1350 \mathrm{w}$, 1095 vs, 759 w, 615 w. UV-visible in $50 \%$ aqueous $\operatorname{DMF}\left[\lambda_{\max } / \mathrm{nm}\left(\varepsilon / \mathrm{M}^{-1} \mathrm{~cm}^{-1}\right)\right]: 658$ (130), 377 (13000), 360 (14000), $272(58000)$. $\mu_{\text {eff }}$ at $298 \mathrm{~K}: 1.81 \mu_{\mathrm{B}}$. Conductivity in $\operatorname{DMF}\left(\Lambda_{\mathrm{M}}\right): 78 \mathrm{~S} \mathrm{~cm}^{2} \mathrm{M}^{-1}$.

\section{$2.3 X$ X-ray Crystallography}

The crystal structure of $[\mathrm{Cu}($ bpy $)(\mathrm{L})]\left(\mathrm{ClO}_{4}\right)(\mathbf{1})$ was obtained by the single-crystal X-ray diffraction method. The green crystals were isolated from an acetonitrile solution on slow evaporation of the solvent. Crystal mounting was done on a glass fiber with epoxy cement. All geometric and intensity data were collected at room temperature using an automated Bruker SMART APEX CCD diffractometer equipped with a fine-focus 1.75 $\mathrm{kW}$ sealed tube Mo- $\mathrm{K}_{\alpha} \mathrm{X}$-ray source $(\lambda=0.71073 \AA)$ with increasing $\omega$ (width of $0.3^{\circ}$ per frame) at a scan speed of $5 \mathrm{sec}$ per frame. Intensity data, collected using $\omega-2 \theta$ scan mode, were corrected for Lorentz-polarization effects and absorption. ${ }^{37}$ Structure solution was done by the combination of Patterson and Fourier techniques and refined by full-matrix least-squares method using the SHELX programs. ${ }^{38}$ Hydrogen atoms of the complex were placed in their calculated positions and refined using a riding model. The non-hydrogen atoms were refined anisotropically. The perspective view of

the molecule was obtained using ORTEP. ${ }^{39}$ CCDC1428741 contains the crystallographic data for this article. The crystallographic parameters are listed in table 1 .

\subsection{Theoretical study}

The energy optimised structures of the complexes $\mathbf{1}$ and 2 were obtained by density functional theory (DFT) calculation. ${ }^{40}$ The hybrid U3LYP functional and LANL2DZ basis set were used in all calculations as incorporated in Gaussian 09 package. ${ }^{41}$ Visualizations of the optimized structures and the MOs were done using Gauss view 5.0. Frequency test was performed to ascertain the stationary points.

\subsection{DNA binding experiments}

The experiments were done using calf thymus (ct) DNA in Tris- $\mathrm{HCl} / \mathrm{NaCl}$ buffer $(5 \mathrm{mM}$ Tris- $\mathrm{HCl}, 5 \mathrm{mM} \mathrm{NaCl}$, $\mathrm{pH}$ 7.2) using DMF solution of the complexes at room temperature following the reported procedures..$^{8,9,17,19}$ The intrinsic equilibrium binding constant $\left(K_{\mathrm{b}}\right)$ of $\mathbf{1}$ and $\mathbf{2}$ to ct-DNA were obtained by McGhee-von Hippel

Table 1. Selected crystallographic data for complex $\mathbf{1}$.

\begin{tabular}{|c|c|}
\hline Formula & ${ }_{22} \mathrm{H}_{20} \mathrm{ClCuN}_{5} \mathrm{O}_{5}$ \\
\hline $\mathrm{FW}_{\mathrm{W}}\left(\mathrm{g} \mathrm{M}^{-1}\right)$ & 533.42 \\
\hline Crystal system & Monoclinic \\
\hline Space group (no.) & $P 2_{1} / \mathrm{c}$ \\
\hline$a(\AA)$ & $11.6846(11)$ \\
\hline$b(\AA)$ & $17.9514(16)$ \\
\hline$c(\AA)$ & $11.0165(10)$ \\
\hline$\alpha=\gamma\left({ }^{\circ}\right)$ & 90.0 \\
\hline$\beta\left({ }^{\circ}\right)$ & $98.215(2)$ \\
\hline$V\left(\AA^{3}\right)$ & 2287.1(4) \\
\hline Z & 4 \\
\hline$T(\mathrm{~K})$ & 293(2) \\
\hline$\rho_{\text {calc }}\left(\mathrm{g} \mathrm{cm}^{-3}\right)$ & 1.595 \\
\hline$\lambda(\AA)\left(\mathrm{Mo} \mathrm{K}_{\alpha}\right)$ & 0.71073 \\
\hline$\mu\left(\mathrm{mm}^{-1}\right)$ & 1.117 \\
\hline$F(000)$ & 1092 \\
\hline Reflections collected & 65193 \\
\hline Unique reflections & 5272 \\
\hline Reflections with $\mathrm{I}>2 \sigma(I)$ & 3302 \\
\hline parameters/restraints & $311 / 0$ \\
\hline Goodness-of-fit on $F^{2}$ & 1.074 \\
\hline$R\left(F_{\mathrm{o}}\right)^{\mathrm{a}}[I>2 \sigma(I)]$ & 0.0566 \\
\hline$w R\left(F_{\mathrm{o}}\right)^{\mathrm{b}}[I>2 \sigma(I)]$ & 0.1303 \\
\hline$R$ [all data] ( $w R$ [all data]) & $0.1079(0.1598)$ \\
\hline Largest difference in peak and hole $\left[\mathrm{e} . \AA^{-3}\right]$ & ] $\quad 0.568,-0.426$ \\
\hline
\end{tabular}

Formula

Fw $\left(\mathrm{g} \mathrm{M}^{-1}\right)$

Crystal system

Space group (no.)

$b(\AA)$

$c(\AA)$

$\beta\left({ }^{\circ}\right)$

$\AA^{3}$

$T(\mathrm{~K})$

293(2)

1.595

1.117

1092

5272

3302

$11 / 0$

0.0566

$w R\left(F_{\mathrm{o}}\right)^{\mathrm{b}}[I>2 \sigma(I)]$

$R$ [all data] ( $w R$ [all data])

$0.1079(0.1598)$

$\overline{{ }^{\mathrm{a}}} R=\Sigma|| F_{\mathrm{o}}|-| F_{\mathrm{c}}|| / \Sigma\left|F_{\mathrm{o}}\right| .{ }^{\mathrm{b}} w R=\left\{\Sigma\left[w\left(F_{\mathrm{o}}^{2}-F_{\mathrm{c}}^{2}\right)^{2}\right] /\right.$ $\left(F_{o}^{2}+2 F_{c}^{2}\right) / 3$. CCDC number: 1428741 . 
$(\mathrm{MvH})$ method using the expression of Bard et al. by monitoring the change of the absorption intensity of the spectral band with increasing concentration of ct-DNA. ${ }^{42,43}$ DNA thermal denaturation experiments were carried out by monitoring the absorbance of ctDNA $(190 \mu \mathrm{M})$ at $260 \mathrm{~nm}$ by varying the temperature from 40 to $90^{\circ} \mathrm{C}$, both in the presence and absence of the complexes $(20 \mu \mathrm{M})$ using a Perkin-Elmer Lambda $650 \mathrm{UV} /$ Vis spectrometer with a temperature controller at an increase rate of $0.5^{\circ} \mathrm{C}$ per min of the solution. The viscosity titrations were done using a Schott Gerate AVS 310 automated viscometer attached with a constant temperature bath at $37( \pm 0.1)^{\circ} \mathrm{C}$ following the experimental procedure reported earlier. ${ }^{8,9,17,19}$ The concentration of ct-DNA stock solution was $150 \mu \mathrm{M}$ (NP) in $5 \mathrm{mM}$ Tris- $\mathrm{HCl}$ buffer. The complex was added gradually so that the concentration of the complexes varied from 0 to $120 \mu \mathrm{M}$. The apparent DNA binding constants were obtained from fluorescence spectral measurements. Ethidium bromide (EB), a known DNA intercalator, did not show any emission in the Tris- $\mathrm{HCl}$ buffer due to solvent quenching. In presence of duplex DNA EB showed red emission at $601 \mathrm{~nm}$ on excitation at $546 \mathrm{~nm}$ due to intercalation. Hence, the fluorescence intensity of EB bound to ct-DNA was monitored upon addition of the complex. On increasing the complex concentration the fluorescence intensity of EB showed a gradual decrease in intensity due to its displacement by the complex. ${ }^{44,45}$ The apparent DNA binding constants $\left(K_{\text {app }}\right)$ of the complexes were obtained using the

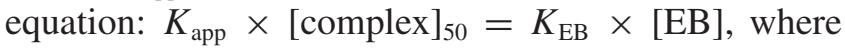
[complex $]_{50}$ is the concentration of the complex at $50 \%$ reduction of the fluorescence intensity, $K_{\mathrm{EB}}=1.0 \times 10^{7}$ $\mathrm{M}^{-1}$ and $[\mathrm{EB}]=2 \mu \mathrm{M}$.

\subsection{DNA Cleavage Experiments}

The DNA cleavage activity of the complexes was studied in presence of external reducing agents to ascertain the chemical nuclease activity and in presence of light in Tris- $\mathrm{HCl}$ buffer medium using SC pUC19 DNA $(0.2 \mu \mathrm{g}, 30 \mu \mathrm{M}, 2686$ base pairs) by agarose gel electrophoresis in $50 \mathrm{mM}$ Tris- $\mathrm{HCl}$ buffer of $\mathrm{pH} 7.2$ and $50 \mathrm{mM} \mathrm{NaCl}$ containing 10\% DMF following reported procedures. ${ }^{8,9,17,19}$ The chemical nuclease activity was studied using glutathione in its reduced form (1 mM). The photo-induced DNA cleavage experiments were carried out in the red light of $647 \mathrm{~nm}(50 \mathrm{~mW})$ using a continuous-wave (CW) Ar-Kr laser (laser beam diameter $=1.8 \mathrm{~mm}$, beam divergence $=0.70 \mathrm{mrad}$, Spectra Physics Water-Cooled Mixed-Gas Ion Laser Stabilite ${ }^{\circledR}$ 2018-RM). The power of the laser beam was measured using Spectra Physics CW Laser Power
Meter (Model 407A). The solution path length used for illumination in the glass vial was $\sim 5 \mathrm{~mm}$. Mechanistic investigations were done using various reactive oxygen species (ROS) quenchers/scavengers to ascertain formation and nature of the ROS.

\subsection{Cytotoxicity from MTT assay}

The cytotoxicity of the complexes was studied using MTT assay in light and dark conditions in human cervical carcinoma (HeLa) cells following reported procedures. ${ }^{17,19}$ The MTT assay method is based on the ability of mitochondrial dehydrogenases of viable cells to cleave the tetrazolium rings of MTT, forming dark purple membrane impermeable crystals of formazan that can be estimated from the spectral measurements in DMSO at $540 \mathrm{~nm} .{ }^{46}$ Photo-irradiation was done with a broad band visible light (400-700 nm, $10 \mathrm{~J} \mathrm{~cm}^{-2}$ ) using Luzchem Photoreactor (Model LZC-1, Ontario, Canada, Sylvania fluorescent white tubes with a fluence rate of $2.4 \mathrm{~mW} \mathrm{~cm}{ }^{-2}$ to provide a total dose of $10 \mathrm{~J}$ $\mathrm{cm}^{-2}$ ). The absorbance was measured at $540 \mathrm{~nm}$ using a Molecular Devices Spectra Max M5 plate reader. Cytotoxicity of the complexes was measured as the percentage ratio of the absorbance of the treated cells to the untreated controls. The cytotoxicity was expressed in terms of the $\mathrm{IC}_{50}$ values which were determined by nonlinear regression analysis using GraphPad Prism 5.

\subsection{DCFDA assay for ROS generation}

DCFDA assay was carried out to detect any generation of intracellular ROS. ${ }^{47}$ Cell permeable DCFDA on oxidation by cellular ROS generates green fluorescent $2^{\prime}, 7^{\prime}$-dichlorofluorescein (DCF) with an emission maxima around $525 \mathrm{~nm} .{ }^{48}$ To detect intracellular ROS generation, HeLa cells were incubated with $2 \mu \mathrm{M}$ of complex 2 for $4 \mathrm{~h}$ followed by photo-exposure to visible light (400-700 nm) for $1 \mathrm{~h}$ in PBS (50 mM phosphate buffer, $\mathrm{pH}, 7.2$ containing $150 \mathrm{mM} \mathrm{NaCl})$. After harvesting the cells by trypsinization, a single cell suspension of $1 \times 10^{6}$ cells $\mathrm{mL}^{-1}$ was prepared. The cells were then treated with $10 \mu \mathrm{M}$ DCFDA in dark for $15 \mathrm{~min}$ at room temperature. The distribution of the HeLa cells, stained by DCFDA, was determined by FACS analysis.

\subsection{Annexin-V FITC and Propidium Iodide (PI) Assay}

To investigate the pathway of cell death, HeLa cells $(4 \times$ $10^{5}$ cells $\left.\mathrm{mL}^{-1}\right)$ were incubated with complex $2(2 \mu \mathrm{M})$ in $10 \%$ DMEM for $4 \mathrm{~h}$, followed by irradiation by visible light of 400-700 $\mathrm{nm}$ for $1 \mathrm{~h}$. The cells were then 
cultured for $12 \mathrm{~h}$, harvested and washed with chilled PBS at $4^{\circ} \mathrm{C}$. The cells were then re-suspended in $100 \mu \mathrm{L}$ Annexin-V binding buffer (100 mM HEPES/ $\mathrm{NaOH}$, pH 7.4 containing $140 \mathrm{mM} \mathrm{NaCl}$ and $2.5 \mathrm{mM}$ $\mathrm{CaCl}_{2}$ ), stained with Annexin-V FITC and PI, and incubated for $15 \mathrm{~min}$ in dark. A $400 \mu \mathrm{L}$ of binding buffer was added to the cells after incubation, and flow cytometry was done for analysis. ${ }^{49}$

\section{Results and Discussion}

\subsection{Synthesis and characterization}

The ternary copper(II) complexes $[\mathrm{Cu}(\mathrm{bpy})(\mathrm{L})]\left(\mathrm{ClO}_{4}\right)$ (1) and $[\mathrm{Cu}(\mathrm{dppz})(\mathrm{L})]\left(\mathrm{ClO}_{4}\right)$ (2), where bpy is 2,2'-bipyridine (in 1), dppz is dipyrido[3,2-a: $2^{\prime}, 3^{\prime}$ c]phenazine (in 2) and L is monoanion of a Schiff base derived from salicylaldehyde and histamine, were prepared in good yield from the reaction of the Schiff base ligand with copper(II) nitrate and the pyridyl base in methanol. The complexes were isolated as their perchlorate salt and were characterized from the analytical and physicochemical data that are given in table 2 . The schematic views of the complexes and the ligands are shown in figure 1. The major peak observed in the ESI-MS spectra was assigned to the $\left[\mathrm{M}-\mathrm{ClO}_{4}\right]^{+}$in acetonitrile. The complexes are 1:1 electrolyte giving molar conductance of $\sim 75 \mathrm{~S} \mathrm{~m}^{2} \mathrm{M}^{-1}$ in DMF at $25^{\circ} \mathrm{C}$. They are one-electron paramagnetic with effective magnetic moment values of $\sim 1.81 \mu_{\mathrm{B}}$. The IR peaks at $\sim 1090 \mathrm{~cm}^{-1}$ and $\sim 1620 \mathrm{~cm}^{-1}$ are assigned to the perchlorate anion and the coordinated $\mathrm{C}=\mathrm{N}$ moiety. ${ }^{50}$ The electronic absorption spectra of the complexes in $50 \%$ aqueous DMF showed the d-d band at $\sim 660 \mathrm{~nm}$. The ligand centered absorption bands were in the UV region. The complexes showed their $\mathrm{n} \rightarrow \pi^{*}$ transition due to the presence of histamine moiety at $\sim 360 \mathrm{~nm}$. The dppz complex 2 showed an additional $\mathrm{n} \rightarrow \pi^{*}$ transition at $377 \mathrm{~nm}$ due to the phenazine moiety (figure 2). ${ }^{19,25}$ The redox active complexes showed only reductive cyclic voltammetric responses involving the metal centre and the polypyridyl bases in DMF-0.1 M TBAP. A quasi-reversible reduction peak observed near $0.0 \mathrm{~V}$ for $\mathbf{1}$ and at $-0.1 \mathrm{~V}$ for $\mathbf{2}$ is due to $\mathrm{Cu}(\mathrm{II})-\mathrm{Cu}(\mathrm{I})$ couple. Complex 2 also showed dppz based ligand reduction peaks at -1.16 and $-1.69 \mathrm{~V}$ vs. SCE.

\subsection{Crystal structure}

Complex 1 was structurally characterized by single crystal X-ray diffraction. It crystallizes in $P 2_{1} / c$ space group of the monoclinic crystal system with four molecules per unit cell. The molecular structure of

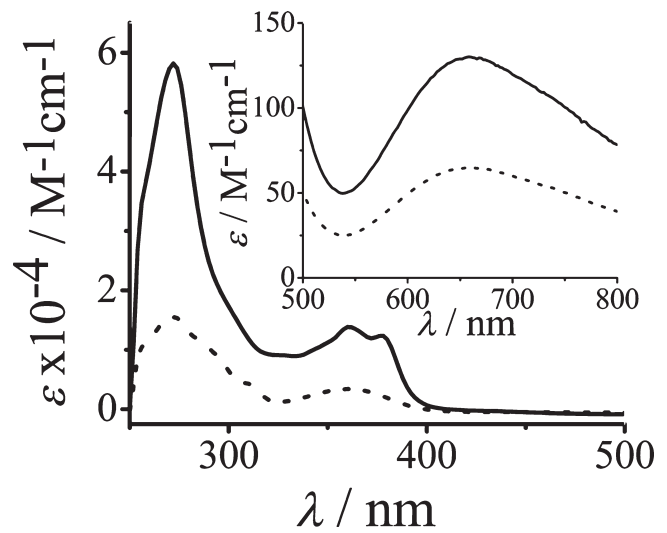

Figure 2. The electronic absorption spectra of the complexes $\mathbf{1}(\cdots)$ and $2(-)$ in $50 \%$ aqueous DMF. The inset shows the $\mathrm{Cu}$ (II) centered $\mathrm{d}-\mathrm{d}$ bands of the complexes in the near-IR region.

Table 2. Selected physicochemical and ct-DNA binding data of the complexes 1 and 2.

\begin{tabular}{lcc}
\hline & $\mathbf{1}$ & $\mathbf{2}$ \\
\hline $\mathrm{IR}^{\mathrm{a}}\left(\mathrm{cm}^{-1}\right)[\bar{U}(\mathrm{C}=\mathrm{N})]$ & 1626 & 1621 \\
Electronic $^{\mathrm{b}}: \lambda(\mathrm{nm})\left(\varepsilon / \mathrm{M}^{-1} \mathrm{~cm}^{-1}\right)$ & $673(65)$ & $658(130)$ \\
$\mu_{\text {eff }}^{\mathrm{c}}\left(\mu_{\mathrm{B}}\right)$ & 1.84 & 1.81 \\
$\Lambda_{\mathrm{M}}^{\mathrm{d}}\left(\mathrm{S} \mathrm{cm} \mathrm{M}^{-1}\right)$ & 72 & 78 \\
$E_{\mathrm{f}}^{\mathrm{e}}(\mathrm{V})$ & -0.05 & -0.1 \\
$K_{\mathrm{b}}^{\mathrm{f}}\left(\mathrm{M}^{-1}\right)$ & $1.5( \pm 0.2) \times 10^{4}$ & $1.3( \pm 0.3) \times 10^{5}$ \\
$\Delta T_{m}^{\mathrm{g}}\left({ }^{\circ} \mathrm{C}\right)$ & 1.4 & 5.1 \\
$K_{a p p}^{\mathrm{h}}\left(\mathrm{M}^{-1}\right)$ & $5.0( \pm 0.5) \times 10^{5}$ & $1.02( \pm 0.2) \times 10^{7}$ \\
\hline
\end{tabular}

${ }^{\mathrm{a}} \mathrm{In} \mathrm{KBr}$ phase. ${ }^{\mathrm{b}}$ Visible electronic spectral band in 50\% aqueous DMF. ${ }^{\mathrm{c}}$ Magnetic moment of solid sample at $298 \mathrm{~K} .{ }^{\mathrm{d}} \Lambda_{\mathrm{M}}$, molar conductance in DMF at $25^{\circ} \mathrm{C}$. ${ }^{\mathrm{e}} \mathrm{Cathodic}$ peak potential in DMF having 0.1 M TBAP as the supporting electrolyte at a scan rate of $50 \mathrm{mVs}^{-1}$. ${ }^{\mathrm{f}}$ Equilibrium ct-DNA binding constant determined from the UV-Visible absorption titration. ${ }^{\mathrm{g}}$ Change in the ct-DNA melting temperature. ${ }^{\mathrm{h}}$ Apparent ct-DNA binding constants determined from the EB displacement assay. 
complex 1 showed a discrete mononuclear pentacoordinated axially elongated square-pyramidal $\mathrm{CuN}_{4} \mathrm{O}$ coordination geometry $(\tau=0.13)$ with the Schiff base

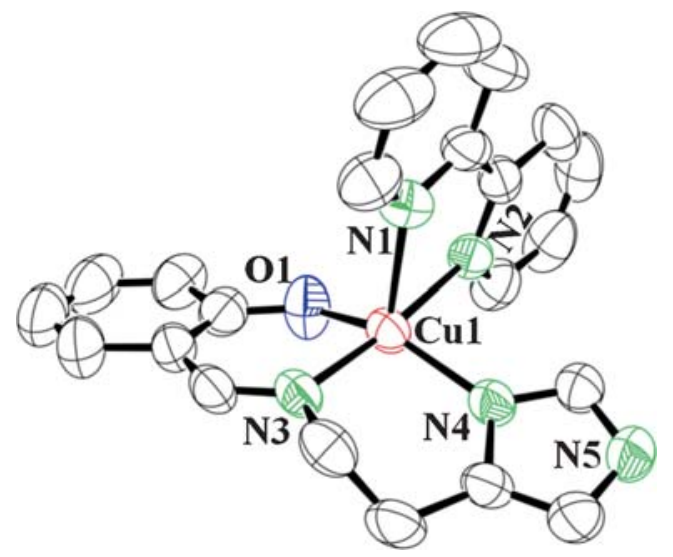

Figure 3. An ORTEP view of the cationic complex of $\mathbf{1}$ with atom labeling scheme for the metal and heteroatoms showing $50 \%$ probability thermal ellipsoids. The hydrogen atoms are not shown for clarity.

Table 3. Selected bond distances $(\AA)$ and angles $\left({ }^{\circ}\right)$ for the bpy complex 1 with e.s.d.s in the parentheses.

$\begin{array}{llll}\mathrm{Cu}(1)-\mathrm{O}(1) & 1.903(3) & \mathrm{O}(1)-\mathrm{Cu}(1)-\mathrm{N}(4) & 150.06(15) \\ \mathrm{Cu}(1)-\mathrm{N}(1) & 2.227(4) & \mathrm{N}(1)-\mathrm{Cu}(1)-\mathrm{N}(2) & 76.79(14) \\ \mathrm{Cu}(1)-\mathrm{N}(2) & 2.015(3) & \mathrm{N}(1)-\mathrm{Cu}(1)-\mathrm{N}(3) & 97.72(14) \\ \mathrm{Cu}(1)-\mathrm{N}(3) & 1.957(3) & \mathrm{N}(1)-\mathrm{Cu}(1)-\mathrm{N}(4) & 98.42(14) \\ \mathrm{Cu}(1)-\mathrm{N}(4) & 1.996(3) & \mathrm{N}(2)-\mathrm{Cu}(1)-\mathrm{N}(3) & 173.84(14) \\ \mathrm{O}(1)-\mathrm{Cu}(1)-\mathrm{N}(1) & 109.49(14) & \mathrm{N}(2)-\mathrm{Cu}(1)-\mathrm{N}(4) & 90.53(13) \\ \mathrm{O}(1)-\mathrm{Cu}(1)-\mathrm{N}(2) & 85.65(14) & \mathrm{N}(3)-\mathrm{Cu}(1)-\mathrm{N}(4) & 93.07(14) \\ \mathrm{O}(1)-\mathrm{Cu}(1)-\mathrm{N}(3) & 93.68(14) & & \end{array}$

and the bpy showing tridentate and bidentate mode of binding to the copper(II) centre. An ORTEP view of the cationic complex is shown in figure 3 and selected bond distances and angles are given in table 3 . The equatorial $\mathrm{Cu}-\mathrm{O}$ bond length is 1.903 (3) $\AA$. The $\mathrm{Cu}-\mathrm{N}$ bond distances in the basal plane are in the range of 1.957(3) to 2.015(3) $\AA$. The axial $\mathrm{Cu}(1)-\mathrm{N}(1)$ bond distance of 2.227(4) $\AA$ is significantly longer in this distorted square-pyramidal geometry. The bpy ligand shows axial-equatorial bidentate chelating mode of binding to the copper(II) centre. That leaves the tridentate Schiff base binding to the metal in a meridional fashion in the basal plane.

\subsection{Theoretical study}

Computational studies were performed to rationalize the photophysical properties of the complexes. The energy optimized structures of the complexes showed that the copper(II) centre is coordinated to the chelating $\mathrm{N}, \mathrm{N}$-donor bpy (in 1) or dppz (in 2), $O, N, N$ donor $\mathrm{HL}$ giving a distorted square pyramidal $\mathrm{Cu}^{\mathrm{II}} \mathrm{N}_{4} \mathrm{O}$ coordination geometry as observed in the crystal structure of complex 1 (figure 4). The bonding parameters are similar to those obtained from the crystal structure. The FMOs (frontier molecular orbitals) of the complexes showed active participation of the metal centre and the Schiff base moiety in forming the HOMOs and contribution of the bpy or dppz ligand in forming the LUMOs (figure 4).

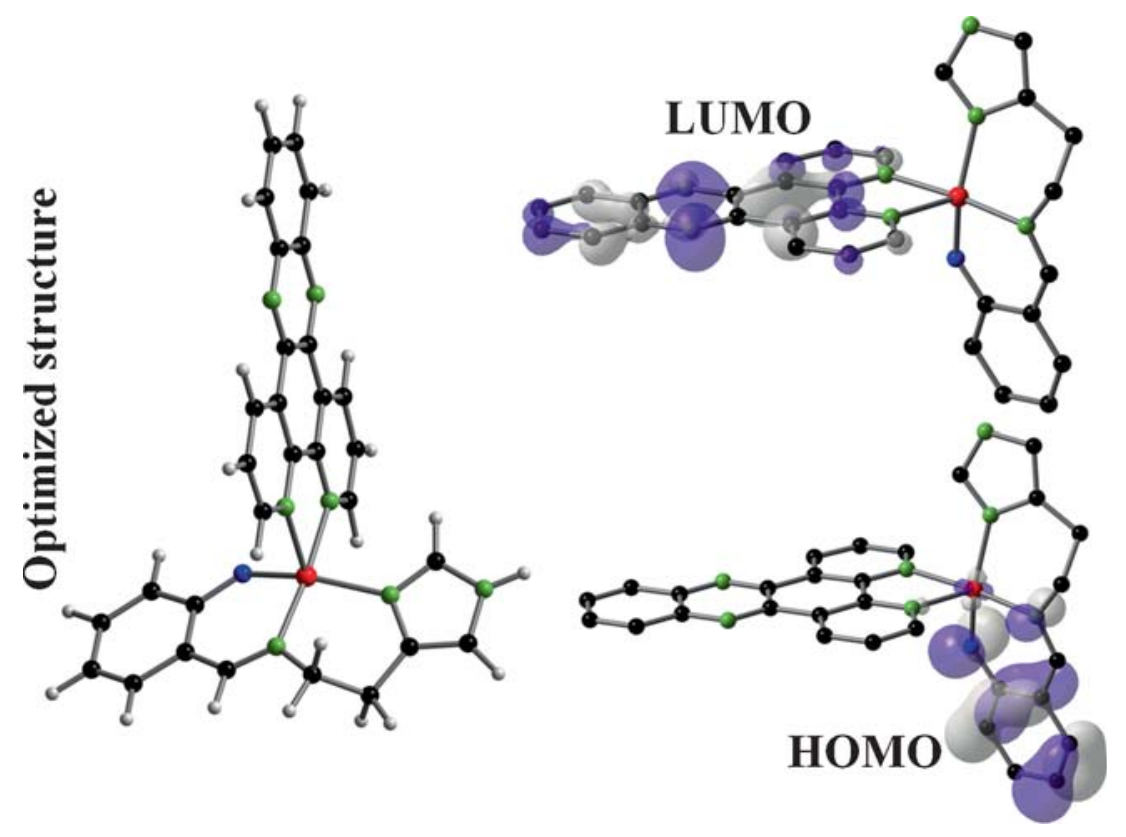

Figure 4. The energy optimized structure of complex 2 along with the FMOs [color codes: $\mathrm{C}$ black, $\mathrm{N}$ green, $\mathrm{O}$ blue, $\mathrm{Cu}$ red, and $\mathrm{H}$ white]. 


\subsection{DNA binding properties}

The equilibrium binding constant $\left(K_{\mathrm{b}}\right)$ of the complexes to ct-DNA were determined by UV-visible absorption titration method. The changes in the absorption spectra of the complexes were monitored on addition of the ct-DNA solution. The complexes showed significant hypochromicity at $\sim 270 \mathrm{~nm}$ upon addition of DNA. The spectral changes for complex $\mathbf{2}$ are shown in figure $5(\mathrm{a})$. The $K_{\mathrm{b}}$ value of the dppz complex is $1.3( \pm 0.3) \times 10^{5} \mathrm{M}^{-1}$ whereas it is $1.5( \pm 0.2) \times 10^{4} \mathrm{M}^{-1}$ for the bpy complex $\mathbf{1}$. The dppz complex shows higher DNA binding strength than its bpy analogue due to presence of planar aromatic phenazine moiety. This is in accordance with the reported results showing high DNA binding strengths for the complexes having ligands with extended planarity. ${ }^{9,17,19,25}$ DNA thermal denaturation studies in phosphate buffer $(\mathrm{pH}=7.2)$ showed stabilizing interaction of the complexes with duplex ct-DNA (figure 5(b)). The change in DNA melting temperature with respect to free duplex ctDNA $\left(\Delta T_{\mathrm{m}}\right)$ for the complexes $\mathbf{1}$ and $\mathbf{2}$ were 1.4 and $5.1^{\circ} \mathrm{C}$, respectively, while it is $10.6^{\circ} \mathrm{C}$ for ethidium bromide (EB). ${ }^{9}$ The DNA melting data indicate partial intercalative mode of binding of the dppz complex 2 .

A similar order is also observed from the viscosity titration experiments. Hoechst dye as a groove binder and EB as a DNA intercalator were used as standards. The plots of $\left(\eta / \eta_{0}\right)^{1 / 3}$ vs. [complex]/[DNA] ratio show partial intercalative binding mode of the dppz complex 2 to ct-DNA, whereas complex 1 showed primarily groove binding propensity (figure 6(a)). The apparent DNA binding constants $\left(K_{\text {app }}\right)$ of the complexes were determined using EB displacement assay in Tris- $\mathrm{HCl}$

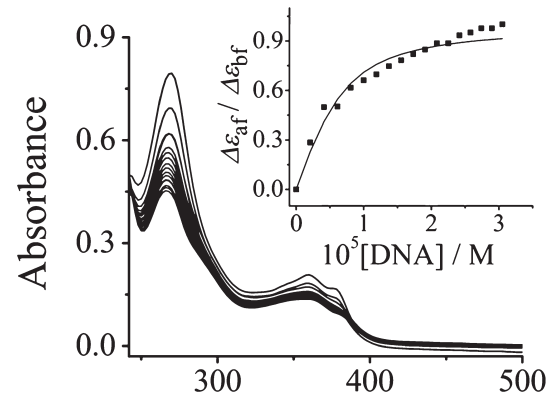

(a)

$\lambda / \mathrm{nm}$

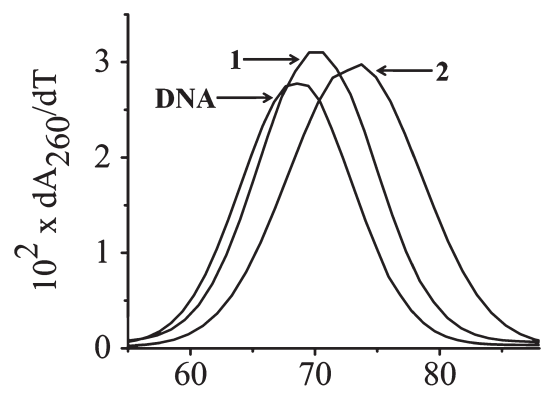

(b)

$\mathrm{T} /{ }^{\mathrm{O}} \mathrm{C}$

Figure 5. (a) Spectral traces showing the effect of gradual addition of ctDNA $(210 \mu \mathrm{M} \mathrm{NP})$ to the $20 \mu \mathrm{M}$ solution of complex 2 in Tris- $\mathrm{HCl}$ buffer medium. Inset shows the plot of $\Delta \varepsilon_{\mathrm{af}} / \Delta \varepsilon_{\mathrm{bf}} v s$. [ct-DNA] for the calculation of binding constant. (b) Thermal denaturation plots for $190 \mu \mathrm{M}$ ct-DNA alone and in the presence of complexes 1 and $2(20 \mu \mathrm{M})$ in $5 \mathrm{mM}$ phosphate buffer at $\mathrm{pH}=7.2$.
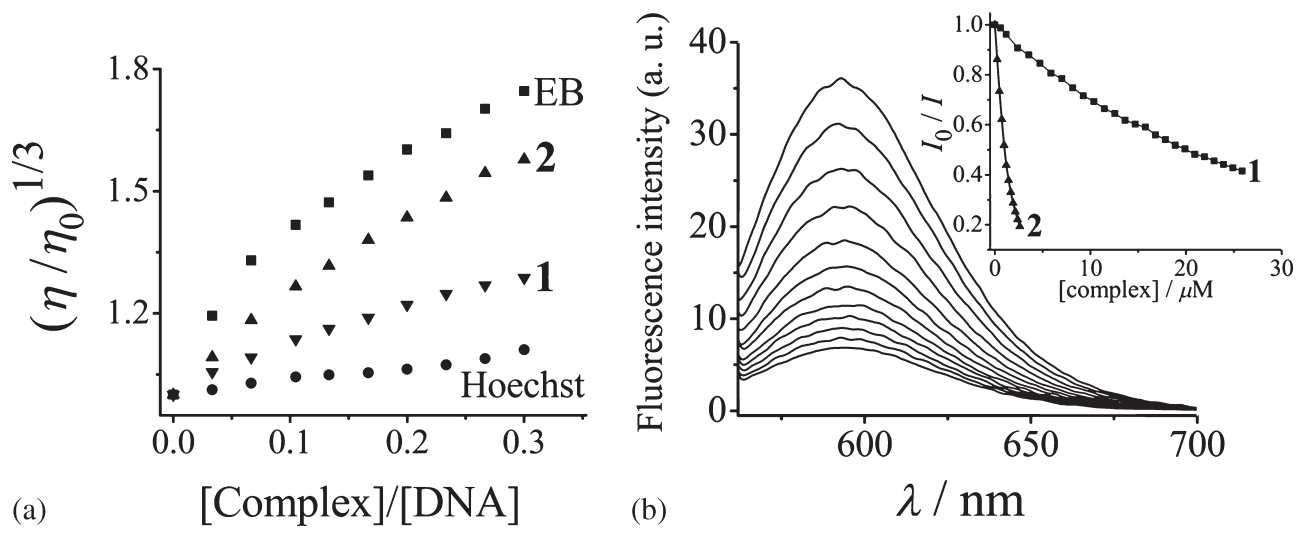

Figure 6. (a) Effect of increasing the concentration of the complexes $\mathbf{1}(\boldsymbol{\nabla}), \mathbf{2}(\boldsymbol{\Delta})$, ethidium bromide $(\mathrm{EB}, \boldsymbol{\square})$ and Hoechst $33258(\bullet)$ on the relative viscosities of $150 \mu \mathrm{M}$ ct-DNA in 5 $\mathrm{mM}$ Tris- $\mathrm{HCl}$ buffer at $37.0( \pm 0.1)^{\circ} \mathrm{C}$. (b) The spectral traces showing the decrease of emission intensity of ct-DNA bound EB with the increasing concentration of the complex 2 in 5 $\mathrm{mM}$ Tris- $\mathrm{HCl}$ buffer medium. The inset shows effect of addition of increasing concentration of the complexes $\mathbf{1}(\boldsymbol{\square})$ and $\mathbf{2}(\boldsymbol{\Delta})$ to an EB bound ct-DNA solution in a $5 \mathrm{mM}$ Tris-HCl buffer $(\mathrm{pH}, 7.2)$ at $25^{\circ} \mathrm{C}$. 
buffer. EB is non-fluorescent in Tris- $\mathrm{HCl}$ due to solvent quenching, but in presence of DNA it emits strong red fluorescence with emission maxima at $601 \mathrm{~nm}$ due to intercalation of EB between the DNA base pairs. ${ }^{44,45}$ Addition of the complex solution into the EB bounded DNA showed displacement of EB from the ct-DNA with a reduction of its emission intensity. This emission band was used as a probe in determining the competitive DNA binding affinity of the complexes. The effect of addition of complex 2 into the DNA-bound EB is shown in figure 6(b). The $K_{\text {app }}$ values for the complexes $\mathbf{1}$ and $\mathbf{2}$ are $5.0( \pm 0.5) \times 10^{5} \mathrm{M}^{-1}$ and $1.02( \pm 0.2)$ $\times 10^{7} \mathrm{M}^{-1}$, respectively. The dppz complex 2 having the planar aromatic moiety exhibits the higher DNA binding affinity compared to its bpy analogue.

\subsection{DNA cleavage activity}

The chemical nuclease activity of the complexes was studied in the dark in presence of glutathione (GSH) in its reduced form $(1 \mathrm{mM})$ as a reducing agent due to the presence of near zero volt (vs. SCE) $\mathrm{Cu}$ (II)-Cu(I) redox couple. The bpy complex $\mathbf{1}$ did not show any activity whereas a $7.5 \mu \mathrm{M}$ of the dppz complex 2 showed $\sim 57 \%$ cleavage of the supercoiled (SC) pUC19 DNA into its nicked circular (NC) form in the presence of GSH. This could be due to higher DNA binding affinity of the dppz complex. The mechanistic aspects of the chemical nuclease activity of $\mathbf{2}$ were studied in presence of various ROS quenchers and scavengers. The hydroxyl radical scavengers like DMSO, KI and catalase inhibited the nuclease activity indicating formation of $\mathrm{OH}$ radical as the reactive oxygen species responsible for the nuclease activity. The singlet oxygen quenchers like sodium azide and TEMP did not inhibit any cleavage activity thus ruling out formation of singlet oxygen as the ROS. The photo-induced DNA cleavage activity of the complexes was studied using near-IR red light of $647 \mathrm{~nm}$. The choice of this wavelength was based on the d-d absorption band at $\sim 660 \mathrm{~nm}$. The complexes were incubated with SC pUC19 DNA $(0.2 \mu \mathrm{g}, 30 \mu \mathrm{M})$ for $1 \mathrm{~h}$ prior to photo-irradiation. The DNA photocleavage data show that only complex $\mathbf{2}$ is active in red light and this could be due to the presence of a photoactive phenazine moiety. Complex 2 showed $\sim 92 \%$ cleavage of DNA at a concentration of $7.5 \mu \mathrm{M}$ (figure 7). The observation of red light induced DNA cleavage is of importance towards developing copper-based photochemotherapeutic agents considering the greater tissue penetration power of red light.

The mechanistic aspects of the pUC19 DNA photocleavage activity of $\mathbf{2}$ were studied to explore any involvement and nature of the ROS (figure 8). The

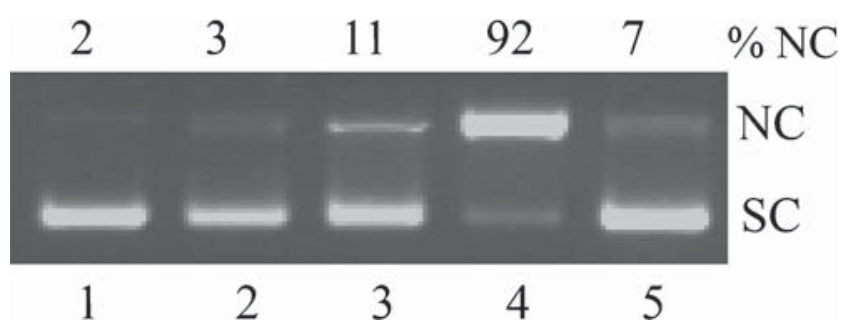

Figure 7. Gel electrophoresis diagram showing the red light-induced $(647 \mathrm{~nm})$ DNA cleavage activity of the complexes 1 and 2 using SC pUC19 DNA $(0.2 \mu \mathrm{g}, 30 \mu \mathrm{M})$ for a photo-exposure time of $1 \mathrm{~h}$ : lane-1, DNA control; lane-2, $\mathrm{DNA}+\mathbf{1}(20 \mu \mathrm{M})$ in the dark; lane-3, DNA + $\mathbf{1}(20 \mu \mathrm{M})$; lane-4, DNA $+2(7.5 \mu \mathrm{M})$; lane-5, DNA $+2(7.5 \mu \mathrm{M})$ in the dark.

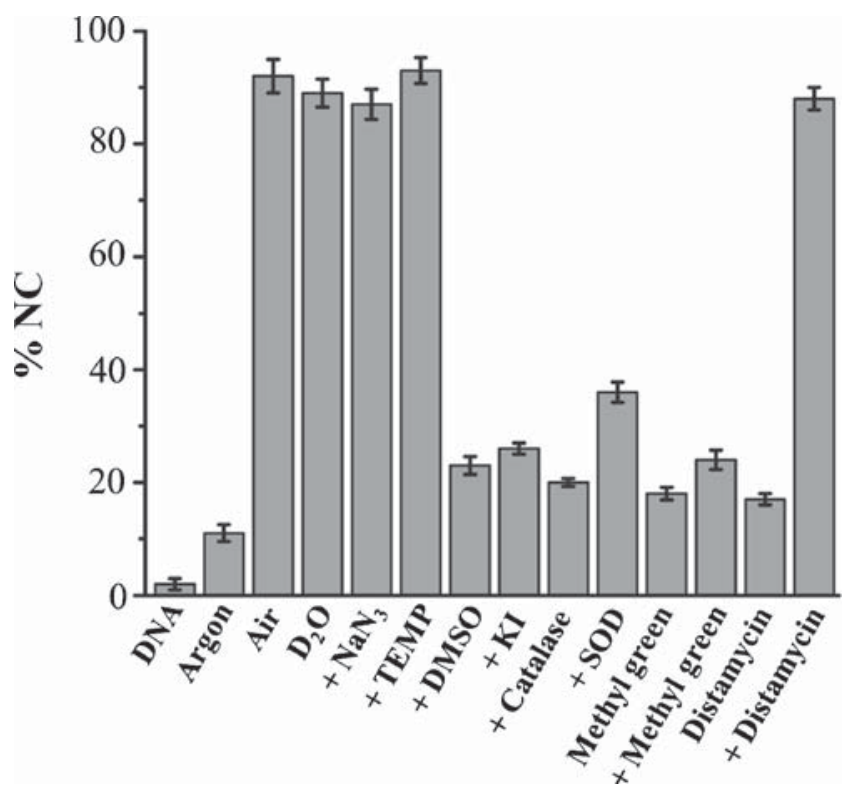

Figure 8. Bar diagram showing the photo-cleavage of pUC19 DNA $(0.2 \mu \mathrm{g}, 30 \mu \mathrm{M})$ by complex $2(7.5 \mu \mathrm{M})$ in the presence of different additives in near-IR light of $647 \mathrm{~nm}$ for an exposure time of $1 \mathrm{~h}\left(\mathrm{D}_{2} \mathrm{O}, 16 \mu \mathrm{L} ; \mathrm{NaN}_{3}, 0.5 \mathrm{mM}\right.$; TEMP, $0.5 \mathrm{mM}$; DMSO, $4 \mu \mathrm{L}$; KI, $0.5 \mathrm{mM}$; catalase, 4 units; SOD, 4 units). The + sign indicates treatment of the specified additive with complex $\mathbf{2}$ and SC DNA.

complex did not show any apparent DNA photocleavage activity in an argon atmosphere thus indicating possible involvement of ROS. Addition of singlet oxygen quenchers, viz., $\mathrm{NaN}_{3}$ and TEMP had no apparent effect on the DNA cleavage activity of the complex. This ruled out formation of singlet oxygen as the ROS. Hydroxyl radical scavengers (catalase, DMSO and KI) showed significant reduction in the DNA photocleavage activity in red light. Generation of superoxide radical as intermediate was evidenced from the inhibitory role of SOD to the DNA photo-cleavage. The results suggested the formation of both hydroxyl and superoxide radicals as the ROS in a photo-redox pathway which 
is known for the copper(II)-dipyridoquinoxaline (dpq) complexes. ${ }^{51,52}$ To determine the DNA minor or major grove binding preference of complex 2 , cleavage experiments were carried out in presence of distamycin as the DNA minor-groove binder and methyl green as the DNA major-groove binder. DNA photocleavage by $\mathbf{2}$ was found to be significantly inhibited in the presence of methyl green $(25 \mu \mathrm{M})$, whereas no such reduction in cleavage activity was observed in the presence of distamycin $(50 \mu \mathrm{M})$ indicating DNA major groove binding preference of the dppz complex 2.

\subsection{Photocytotoxicity from MTT Assay}

The cytotoxicity of the complexes $\mathbf{1}$ and $\mathbf{2}$ was studied in human cervical cancer (HeLa) cells by MTT assay both in the dark and upon photo-irradiation with visible light (400-700 nm). A dose-dependent anti-proliferative activity of the complexes was observed. Photo-exposure with visible light resulted in an enhanced cytotoxicity of complex 2 due to the presence of photoactive phenazine moiety. The dppz complex 2 showed $\sim 10$ fold increase in cytotoxicity in visible light $(400-700 \mathrm{~nm})$ when compared to that in the dark thus giving moderate PDT effect (figure 9). Importantly, complex $\mathbf{1}$ which lacks a photoactive moiety failed to induce any phototriggered enhancement of cytotoxicity giving $\mathrm{IC}_{50}$ values of $10.3 \pm 0.8 \mu \mathrm{M}$ in the dark and $6.8 \pm 0.4 \mu \mathrm{M}$ on light irradiation indicating no apparent PDT effect. The $\mathrm{IC}_{50}$ values of 2 were found to be $1.2 \pm 0.5 \mu \mathrm{M}$ with visible light irradiation, while it is $12.8 \pm 0.7 \mu \mathrm{M}$ in the dark. The dppz ligand gave an $\mathrm{IC}_{50}$ value of $60.1 \pm 2.3 \mu \mathrm{M}$ in visible light under similar experimental condition. This ligand did not show any apparent cytotoxicity $\left(\mathrm{IC}_{50}>100 \mu \mathrm{M}\right)$ in HeLa cells in the dark. The Schiff base ligand (HL) also did not show any

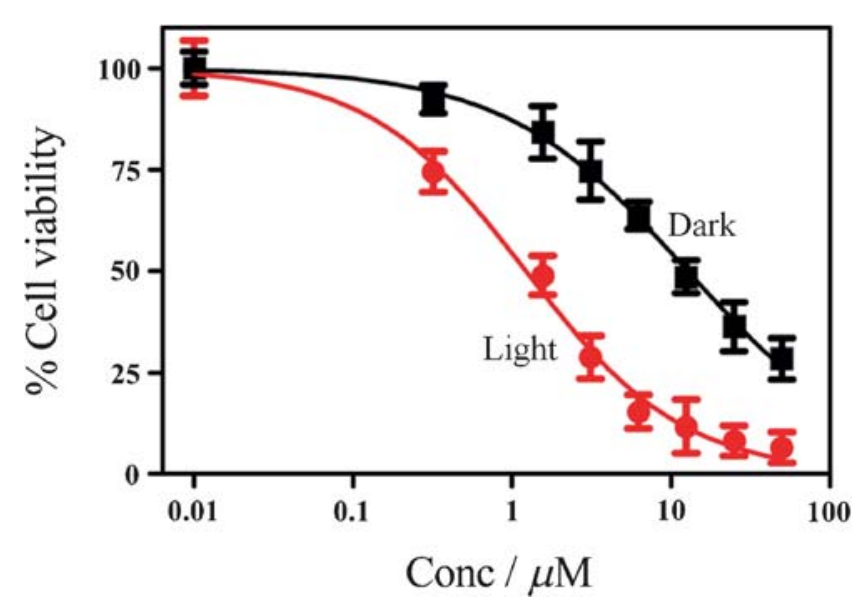

Figure 9. Photocytotoxicity of complex 2 in HeLa cells on $4 \mathrm{~h}$ incubation in the dark (D) followed by exposure to visible light (L) of 400-700 $\mathrm{nm}\left(10 \mathrm{~J} \mathrm{~cm}^{-2}\right)$ for $1 \mathrm{~h}$. cytotoxicity on light irradiation or in the dark $\left(\mathrm{IC}_{50}>\right.$ $100 \mu \mathrm{M})$.

\subsection{DCFDA Assay for ROS}

We examined any generation of intracellular ROS by complex 2 on visible light (400-700 nm) exposure in HeLa cells using DCFDA assay. DCFDA, a cell permeable fluorogenic probe, on oxidation by intracellular ROS generates green fluorescent DCF with an emission maxima at $525 \mathrm{~nm}$ which can be examined by flow cytometry. ${ }^{47,48}$ The cells treated with the dppz complex $\mathbf{2}$ in the dark did not show any significant generation of DCF. However, cells treated with the complex on exposure to visible light (400-700 nm) showed a significant increase in the intensity of the intracellular emission indicating generation of fluorescent DCF via the ROS induced oxidation of non-fluorescent DCFDA (figure $10)$. The assay data suggest generation of ROS only on visible light irradiation with insignificant quantity in the dark.

\subsection{Apoptosis from Annexin V-FITC/PI assay}

This assay which provides a convenient way to detect apoptosis was performed in HeLa cells with the dppz complex 2 . The early stages of apoptosis are marked by the flipping of phosphatidylserine from the inner surface of the plasma membrane to the outer surface. This can be readily detected by a fluorophore conjugated annexin $\mathrm{V}$ protein which is known to bind the surface exposed phosphatidylserine. ${ }^{49}$ The assay is based on dual staining by green fluorescent annexin VFITC (fluorescein isothiocyanate) and propidium iodide (PI, a red fluorescent DNA binding dye). The cells

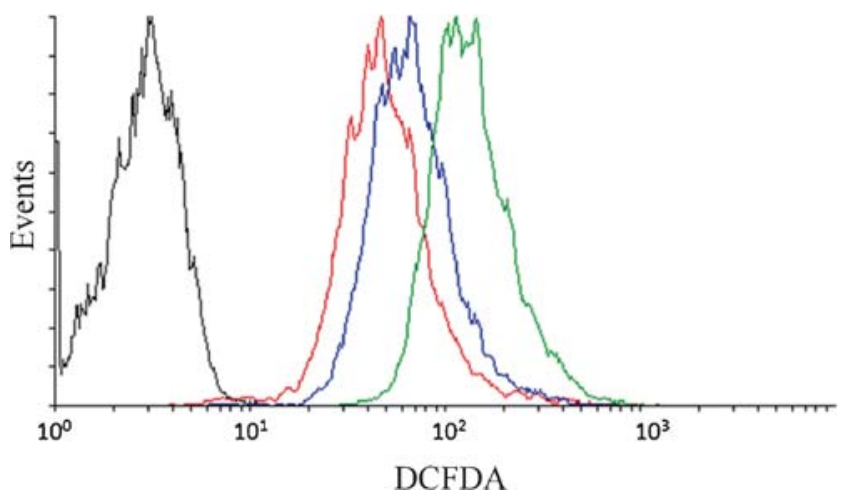

Figure 10. The DCFDA assay to detect generation of any ROS in the HeLa cells on exposure to light (400-700 nm). Colour code: black, cells only; red, cells + DCFDA; blue, cells + DCFDA + 2 (in dark); green, cells + DCFDA + complex 2 (in light). Generation of ROS is marked by the shift in the fluorescence intensity. 


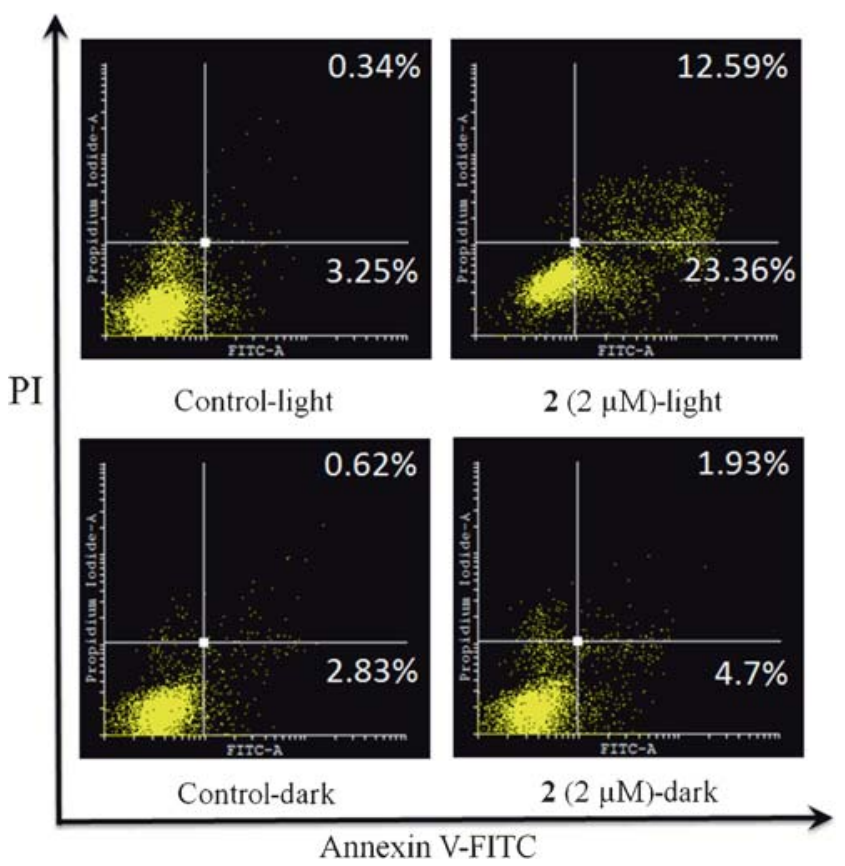

Figure 11. FACS analysis of Annexin-V FITC and PI stained HeLa cells undergoing apoptosis induced by complex 2 under darkness and upon visible light (400-700 nm) exposure.

undergoing early apoptosis are stained only by annexin V-FITC, while the late apoptotic cells are dual stained by both the dyes having a compromised plasma membrane which allows PI entry. The necrotic cell population is stained only by PI. To study whether complex 2 could induce visible light-mediated apoptotic cell death, we stained the HeLa cells that were pretreated with $2 \mu \mathrm{M}$ of the complex in the dark as well as in light with Annexin V-FITC and PI. The results indicated that complex 2 induced significant apoptosis only after visible light (400-700) irradiation (figure 11). About $23 \%$ population of the cells were in an early apoptotic stage and $\sim 13 \%$ of the cells were in a late apoptotic stage. Cell population in the necrotic mode was found to be negligible. In the dark, the complex did not induce any significant cell death at this concentration. The data suggest an overall apoptotic nature of the photo-induced cell death.

\section{Conclusions}

Ternary pyridyl copper(II) complexes of a Schiff base derived from salicylaldehyde and histamine is shown to display red light induced plasmid pUC19 DNA cleavage activity and visible light assisted photocytotoxicity in HeLa cancer cells. The complexes with $\mathrm{CuN}_{4} \mathrm{O}$ square pyramidal coordination geometry showed intercalative ct-DNA binding. The dppz complex $\mathbf{2}$ is an excellent photocleaver of DNA in red light of $647 \mathrm{~nm}$ by generating hydroxyl radicals as the ROS via a photoredox pathway involving the redox active metal center. Unlike other copper(II) complexes of phenanthroline bases that are known to show undesirable high chemical nuclease activity, the dppz copper(II) complex with moderate chemical nuclease activity is suitable for PDT applications. Complex 2 displays significant photocytotoxicity in HeLa cells upon visible light irradiation, while remaining less-toxic under darkness. The cell death upon photo-exposure is via apoptotic pathway most likely by generation of intracellular ROS. Considering the bio-essential nature of copper, the presence of a low-energy d-d band within the PDT spectral window and the biocompatibility of the ligands used, the results are of significant importance towards developing copper-based PDT agents.

\section{Supplementary Information (SI)}

All additional information pertaining to the characterization of the complexes using ESI-MS technique (Figures S1, S2), IR spectra (Figures S3, S4), cyclic voltammograms (Figure S5), unit cell packing diagram of complex 1 (Figure S6), energy optimised structure of 1 along with FMO (Figure S7), EB displacement assay plot for complex 1 (Figure S8), Gel diagram (Figure S9), MTT assay data of complex 1 (Figure S10) and coordinates for the energy minimized structures (Tables $\mathrm{S} 1, \mathrm{~S} 2$ ) are given as supporting information, available at www.ias.ac.in/chemsci.

\section{Acknowledgements}

We thank the Department of Science and Technology (DST), Government of India, for financial support (SR/S5/MBD-02/2007). ARC thanks the DST for J.C. Bose national fellowship and the Alexander von Humboldt Foundation, Germany, for donation of an electrochemical system. S.B. thanks Indian Institute of Science (IISc) for a postdoctoral fellowship. A.D. thanks the University Grants Commission (UGC), New Delhi, for research fellowship. K.S.M. thanks Indian Academy of Sciences for a summer teacher fellowship. The use of the FACS facility of the Department of Biotechnology, Government of India, is gratefully acknowledged.

\section{References}

1. Smith N A and Sadler P J 2013 Phil. Trans. R. Soc. A 37120120519

2. Chakravarty A R and Roy M 2012 Prog. Inorg. Chem. 57119 
3. Canelon I R and Sadler P J 2013 Inorg. Chem. 5212276

4. Schatzschneider U 2010 Eur. J. Inorg. Chem. 1451

5. Knoll J D and Turro C 2015 Coord. Chem. Rev. 282-283 110

6. Mari C, Pierroz V, Ferrari S and Gasser G 2015 Chem. Sci. 62660

7. Banerjee S and Chakravarty A R 2015 Acc. Chem. Res. 482075

8. Banerjee S, Prasad P, Khan I, Hussain A, Kondaiah P and Chakravarty A R 2014 Z. Anorg. Allg. Chem. 640 1195

9. Banerjee S, Pant I, Khan I, Prasad P, Hussain A, Kondaiah P and Chakravarty A R 2015 Dalton Trans. 44 4108

10. Chifotides H T and Kim Dunbar K R 2005 Acc. Chem. Res. 38146

11. Banerjee S, Dixit A, Shridharan R N, Karande A A and Chakravarty A R 2014 Chem. Commun. 505590

12. Sarkar T, Banerjee S and Hussain A 2015 RSC Adv. 5 16641

13. Spring B Q, Rizvi I, Xua N and Hasan T 2015 Photochem. Photobiol. Sci. 141476

14. Bonnett R 2000 In Chemical Aspects of Photodynamic Therapy (Gordon \& Breach: London UK)

15. Celli J P, Spring B Q, Rizvi I, Evans C L, Samkoe K S, Verma S, Pogue B W and Hasan T 2010 Chem. Rev. 110 2795

16. Moriwaki S I, Misawa J, Yoshinari Y, Yamada I, Takigawa M and Tokura Y 2001 Photodermatol. Photoimmunol. Photomed. 17241

17. Banerjee S, Dixit A, Karande A A and Chakravarty A R 2015 Eur. J. Inorg. Chem. 447

18. Maity B, Roy M, Banik B, Majumdar R, Dighe R R and Chakravarty A R 2010 Organometallics 293632

19. Banerjee S, Hussain A, Prasad P, Khan I, Banik B, Kondaiah P and Chakravarty A R 2012 Eur. J. Inorg. Chem. 3899

20. Mackay F S, Woods J A, Heringová P, Kašpárková J, Pizarro A M, Moggach S A, Parsons S, Brabec V and Sadler P J 2007 Proc. Natl. Acad. Sci. U.S.A. 10420743

21. Butler J S, Woods J A, Farrer N J, Newton M E and Sadler P J 2012 J. Am. Chem. Soc. 13416508

22. Carrington S J, Chakraborty I and Mascharak P K 2013 Chem. Commun. 4911254

23. Garner R N, Gallucci J C, Dunbar K R and Turro C 2011 Inorg. Chem. $\mathbf{5 0} 9213$

24. Sgambellone M A, David A, Garner R N, Dunbar K R and Turro C 2013 J. Am. Chem. Soc. 13511274

25. Banerjee S, Prasad P, Hussain A, Khan I, Kondaiah P and Chakravarty A R 2012 Chem. Commun. 487702

26. Goswami T K, Chakravarthi B V S K, Roy M, Karande A A and Chakravarty A R 2011 Inorg. Chem. 508452

27. Hussain A, Somyajit K, Banik B, Banerjee S, Nagaraju G and Chakravarty A R 2013 Dalton Trans. 42 182
28. Bhattacharyya A, Dixit A, Mitra K, Banerjee S, Karande A A and Chakravarty A R 2015 Med. Chem. Commun. 6846

29. Basu U, Khan I, Hussain A, Kondaiah P and Chakravarty A R 2012 Angew. Chem. Int. Ed. 512658

30. Balaji B, Balakrishnan B, Perumalla S, Karande A A and Chakravarty A R 2014 Eur. J. Med. Chem. 85 458

31. Banerjee S, Dixit A, Kumar A, Mukherjee S, Karande A A and Chakravarty A R 2015 Eur. J. Inorg. Chem. 3986

32. Santini C, Pellei M, Gandin V, Porchia M, Tisato F and Marzano C 2014 Chem. Rev. 114815

33. Jaividhya P, Ganeshpandian M, Dhivya R, Akbarsha M A and Palaniandavar M 2015 Dalton Trans. 4411997

34. Medina V A and Rivera E S 2010 Br. J. Pharmacol. 161 755

35. Perrin D D, Armarego W L F and Perrin D R 1980 In Purification of Laboratory Chemicals (Pergamon Press: Oxford)

36. Collins J G, Sleeman A D, Aldrich-Wright J R, Greguric I and Hambley T W 1998 Inorg. Chem. 373133

37. Walker N and Stuart D 1983 Acta Crystallogr. Sect. A: Found. Crystallogr. A39 158

38. Sheldrick G M 2008 Acta Crystallogr. A64 112

39. Johnson C K, ORTEP-III, Report ORNL-5138 (Oak Ridge National Laboratory: Oak Ridge, TN) (1976)

40. Hay P J and Wadt W R 1985 J. Chem. Phys. 82284

41. Frisch M J et al. 2009 GAUSSIAN 09, Revision A.02 (Gaussian Inc.: Wallingford, CT)

42. McGhee J D and Von Hippel P H 1974 J. Mol. Biol. 86 469

43. Carter M T, Rodriguez M and Bard A J 1989 J. Am. Chem. Soc. 1118901

44. Lee M, Rhodes A L, Wyatt M D, Forrow S and Hartley J A 1993 Biochemistry 324237

45. Coheoyt $\mathrm{G}$ and Eisenberg H 1969 Biopolymers 845

46. Mosmann T 1983 J. Immunol. Methods 6555

47. Gomes A, Fernandes E and Lima J L F C $2005 \mathrm{~J}$. Biochem. Biophys. Methods $\mathbf{6 5} 45$

48. Takanashi T, Ogura Y, Taguchi H, Hashizoe M and Honda Y 1997 Invest. Ophthalmol. Vis. Sci. 38 2721

49. Soni C and Karande A A 2010 Mol. Immunol. 47 2458

50. Nakamoto K 1997 In Infrared and Raman Spectra of Inorganic and Coordination Compounds (John Wiley \& Sons: New York)

51. Dhar S, Senapati D, Das P K, Chattopadhyay P, Nethaji M and Chakravarty A R 2003 J. Am. Chem. Soc. 125 12118

52. Santra B K, Reddy P A N, Neelakanta G, Mahadevan S, Nethaji M and Chakravarty A R 2002 J. Inorg. Biochem. 89191 